\title{
He bends the rules to suit himself
}

\author{
Ho Manh Toan
}

AISDL

Hanoi, 27-11-2020

\begin{abstract}
"He bends the rules to suit himself." - Sir Alf Ramsey said about Maradona, who passed away on November 25, 2020. Indeed, for all disciples of football, it is hard not to know his name. Probably even the outsiders know the Hand of God. Indeed, he is an otherworldly player, but he is also as corrupted as a man could be. I recommend Ryan O'hanlon's GQ piece [1], and Rory Smith's on The New York Times [2]. They are fantastic essays on Maradona.

I only know him through my father's nostalgia, the compilation videos on YouTube, and the comparison with Messi. It is hard to imagine his era. However, unlike the perfection of modern athletes, Maradona is possibly closer to what I have experienced in my life. On my football field, we are neither strong nor skillful. Our touches were off most of the time. Thus, winning a game means using whatever ways you can come up on the spot. Just run and react. That is how most of my amateur games are.
\end{abstract}

As Ronaldinho once said: "I learned all about life with a ball at my feet," I like to use a football analogy whenever I need to explain something. For instance, I once suggested that research is a team sport [3]. Furthermore, a team always needs a player with both the ability and the mentality: A player who bends the ball to his will, and bends the rules to suit himself.

Certainly, science is probably the most disciplined field in the world. We need ethical research, robust and reproducible results. Our methods must be legitimate. Our logic has to be unbreakable. However, scientists also fit the above description quite nicely. Otherwise, who can offer radical ideas and breaking barriers? [4]. I can think of Albert Einstein, Kurt Godel, or Grigori Perelman, who were not bounded by the present.

The ability, or in this case: the intelligence, is easy to understand. They are just simply smarter than everyone else. However, the "bending the rules to suit himself" should not be understood as slyness or trickery. Instead, it is the willingness to go beyond the accepted norms. I know many experienced researchers are often insisting that they belong to a discipline only. Similarly, there are my friends who keep on finding jobs in a specific industry because it is their expertise. A person can only truly master a limited number of skills. However, it does not mean that those skills cannot be translated across multiple jobs. Back to football, look at how the top teams have embraced players who can play in several positions, or how even goalkeepers are demanded to have good ball control skills.

My research team often discusses which works of ours will eventually stand the test of time $[5,6,7,8]$. We also find ways to promote these works too. Working in a 
developing country like Vietnam, you cannot expect the kind of attention like in developed countries. My mentor once suggested that "the real value of science is in improving quality of life" [9]. Thus, these works still need a bit more history to become the real value. However, there is always a strong feeling that things will eventually be fine, because we have tried our best to make sure of that.

\section{References}

[1] O'hanlon, R. (2020). Diego Maradona was a deeply human superstar. GQ. Retrieved from https://www.gq.com/story/diego-maradona-legacy

[2] Smith, R. (2020). The most human of immortals. The New York Times. Retrieved from https://www.nytimes.com/2020/11/25/sports/soccer/diego-maradona.html

[3] Ho, M. T., Nguyen, T. H. K, Vuong, T. T., Nguyen, M. H., \& Ho, M. T. (10 Oct, 2019). To walk on the Penrose stairs of science. Behavioural and Social Sciences at Nature Research. URL: https://socialsciences.nature.com/channels/2140-is-it-publish-orperish/posts/54541-to-walk-on-the-penrose-stairs-of-science.

[4] Vuong, Q. H. (2019). Breaking barriers in publishing demands a proactive attitude. Nature Human Behaviour, 3(10), 1034.

[5] Vuong, Q. H., La, V. P., Vuong, T. T., Nguyen, V. H., Ho, M. T. et al. (2018). Cultural additivity: Behavioural insights from the interaction of Confucianism, Buddhism, and Taoism in folktales. Palgrave Communications, 4, 143.

[6] Vuong, Q. H., Nguyen, H. K. T., Ho, M. T., La, V. P., Vuong, T. T. et al. (2020). On how religions could accidentally incite lies and violence: Folktales as a cultural transmitter. Palgrave Communications, 6, 82.

[7] Vuong, Q. H. (2020). The Semiconducting Principle of Monetary and Environmental Values Exchange. OSF Preprints. DOI: 10.31219/osf.io/nv3yz.

[8] Vuong, Q. H., Napier, N. K. (2015). Acculturation and global mindsponge: an emerging market perspective. International Journal of Intercultural Relations, 49, 354-367.

[9] Vuong, Q. H. (2018). The (ir)rational consideration of the cost of science in transition economies. Nature Human Behaviour, 2(1), 5. 